\title{
Myo-inositol hexakisphosphate (phytate) inhibits calcium carbonate crystallisation in hard water
}

\author{
Félix Grases*, Joan Perelló, Bernat Isern and Antonia Costa-Bauzá \\ Laboratory of Renal Lithiasis Research, Institute of Health Sciences Research (IUNICS), University of Balearic Islands, \\ 07122 Palma de Mallorca, Spain
}

\begin{abstract}
A batch system and a flow system with synthetic water were used to study calcium carbonate precipitation and phytate crystallisation inhibitory effects. Afterwards, phytate inhibitory effects on calcium carbonate crystallisation were tested in a real system, working with a cistern filled with hard water. Finally, the effects of phytate on calcium carbonate crystallisation were compared with another phosphate derivative and with a chelating agent.

The results obtained with the batch system demonstrated that $1.52 \mu \mathrm{M}$ of phytate completely avoided calcium carbonate crystallisation when the calcium concentration was less than $7.9 \mathrm{mM}$ and the carbonate concentration was $5.83 \mathrm{mM}$. The results corresponding to the flow system showed that $3.03 \mu \mathrm{M}$ of phytate led to a $95 \%$ reduction of calcium carbonate scale formation on a copper pipe after $48 \mathrm{~h}$, operating at $30^{\circ} \mathrm{C}$. In addition, in a full-scale system, the dissolved calcium and bicarbonate concentration was increased for a given time when adding phytate to the cistern. Finally, using a batch system, it was demonstrated that phytate effects on calcium carbonate crystallisation reduction were superior to those shown by triphosphate and EDTA.

The results presented demonstrate that phytate at very low concentrations can be used to prevent calcium carbonate scale formation without changing the mineral composition of water due to its capacity as a crystallisation inhibitor.
\end{abstract}

Keywords: phytate, inhibition, calcium carbonate, scale formation, water hardness

\section{Introduction}

The driving force for crystallisation is supersaturation. Thermodynamically, a supersaturated system is unstable, and depending on kinetic factors (promoters or crystallisation inhibitors) solids formation will be enhanced or delayed. Water hardness can lead to scale formation, consisting primarily of $\mathrm{CaCO}_{3}$ but including other salts such as $\mathrm{CaSO}_{4}$, resulting from high supersaturation. This problem is critical in systems working at high temperatures, such as boilers. In these systems hard water cannot be used, because of the risks of breakages and explosions.

Calcium carbonate is the most abundant mineral in nature (Sikes, 1988) and is present as three polymorphic varieties, calcite, aragonite and vaterite. Morphological control of calcium carbonate can be achieved using different additives (Kang, 2005; Kim, 2005; Hou, 2005). Among the water-softening methods proposed to avoid calcium carbonate scale formation are ionic exchangers, consisting of zeolites (Malik, 2001; Semenov, 2004) and ion-exchange resins (Gwon, 2002); reverse osmosis systems (Hirayama, 1990); and the formation of stable complexes with EDTA (Westin, 2005) and phosphates such as tripolyphosphate (Arai 1968). Recently, electrodialysis has been used to remove calcium and magnesium from solutions (Toti, 2000; Kabay, 2002).

Calcium carbonate precipitation can also be reduced or delayed by using so-called crystallisation inhibitors. These substances prevent or disturb precipitation by adsorbing onto the surfaces of nuclei as they form or onto the faces of growing

* To whom all correspondence should be addressed.

政 +34 97 1173257; fax: +3497 1173426;

e-mail: fgrases@uib.es

Received 27 February 2007; accepted in revised form 29 June 2007. crystals, respectively, thereby modifying the kinetics of crystallisation. Among the agents described as calcium carbonate crystallisation inhibitors are ions such as $\mathrm{Fe}^{2+}, \mathrm{Fe}^{3+}, \mathrm{Mg}^{2+}$ and $\mathrm{Zn}^{2+}$ (Reddy, 1980; Macadam, 2004; Hasson, 2004; Coetzee, 1998).

Calcium carbonate crystallisation has also been widely studied using the inhibitory properties of other compounds, among them phosphates and phosphonates (Reddy (1972; 1973); Nancollas, 1975), aminophosphonates (Guo, 2004), polyacrylic acid (Klepetsanis $(1999 ; 2000)$ ), and copolymers containing maleic acid (Klepetsanis, 1998).

Myo-inositol hexakisphosphate (phytate) is a powerful inhibitor of the crystallisation of calcium salts and has been shown to prevent calcium renal lithiasis (Grases (1999; 2000a)). Phytate levels found in tissues reflect dietary intake (Grases (2001a; 2001b)). Previous work has found that phytate only manifested toxic effects at very high doses (the $\mathrm{LD}_{50}$ value for male rats was $1.3 \mathrm{mmol} \cdot \mathrm{kg}^{-1}$ administered orally as sodium phytate (Ichikawa, 1987). Administration of phytate as the natural food salt (phytin: calcium magnesium phytate) at amounts that provide maximum absorption equivalent to doses that correspond to the consumption of the so-called 'Mediterranean diet' ( 1 to $2 \mathrm{~g}$ phytate/d) were not found to have any chronic effect (Grases, 2004). Furthermore, in the field of renal lithiasis and cardiovascular calcifications it is the most effective crystallisation inhibitor of calcium oxalate (Grases (1994; 1996a; 1996b)), its efficacy on brushite (calcium phosphate) even being superior to other phosphate derivatives such as pyrophosphate, hexametaphosphate, etidronate or triphosphate (Grases $(2000 \mathrm{~b} ; 2007))$. All these data led us to believe that phytate could be used as an alternative to scale prevention and we therefore assayed the crystallisation inhibition properties of phytate on calcium carbonate solids formation by adding it to supersaturated water. 


\begin{tabular}{|l|c|l|c|}
\hline \multicolumn{4}{|c|}{ TABLE 1 } \\
Composition of synthetic hard water \\
\hline \multicolumn{2}{|c|}{ Solution A $\boldsymbol{\mu} \boldsymbol{\mu}$ M) } & \multicolumn{2}{c|}{ Solution $\mathbf{B}(\boldsymbol{\mu})$} \\
\hline $\mathrm{MgSO}_{4} \cdot 7 \mathrm{H}_{2} \mathrm{O}$ & 162.3 & $\mathrm{MgSO}_{4} \cdot 7 \mathrm{H}_{2} \mathrm{O}$ & 162.3 \\
\hline $\mathrm{KNO}_{3}$ & 29.7 & $\mathrm{KNO}_{3}$ & 29.7 \\
\hline $\mathrm{Ca}\left(\mathrm{NO}_{3}\right)_{2} \cdot 2 \mathrm{H}_{2} \mathrm{O}$ & 400 & $\mathrm{Ca}\left(\mathrm{NO}_{3}\right)_{2} \cdot 2 \mathrm{H}_{2} \mathrm{O}$ & 400 \\
\hline $\mathrm{CuSO}_{4} \cdot 5 \mathrm{H}_{2} \mathrm{O}$ & 0.802 & $\mathrm{CuSO}_{4} \cdot 5 \mathrm{H}_{2} \mathrm{O}$ & 0.802 \\
\hline $\mathrm{ZnCl}_{2}$ & 14.66 & $\mathrm{ZnCl}_{2}$ & 14.66 \\
\hline $\mathrm{CaCl}_{2}$ & $0-12500$ & $\mathrm{NaHCO}_{3}$ & 11670 \\
\hline
\end{tabular}

\section{Methods}

\section{Preparation of synthetic hard water}

Synthetic hard water was prepared by mixing equal volumes of Solutions A and B, as shown in Table 1. Solution A was stored for a maximum of 1 week at $4^{\circ} \mathrm{C}$, and Solution $\mathrm{B}$ was always prepared immediately before use. Chemicals of reagent-grade purity were dissolved in deionised, redistilled water. All solutions were filtered through a $0.45 \mu \mathrm{m}$ pore filter before use.

\section{Calcium carbonate precipitation using a batch system and study of phytate crystallisation inhibitory effects}

To study calcium carbonate crystal formation in synthetic hard water, turbidimetric measurements were performed by means of a photometer (Metrohm 662) equipped with a fibre-optic light guide measuring cell with an attached light path $2 \times 10 \mathrm{~mm}$ reflector, using monochromatic light $(550 \mathrm{~nm})$. Crystallisation processes were performed at $25^{\circ} \mathrm{C}$ using cylindrical tubes (height $100 \mathrm{~mm}$, inner diameter $150 \mathrm{~mm}$ ). Five $\mathrm{m} \ell$ of Solution A were added to the crystallisation tube, followed by $5 \mathrm{~m} \ell$ of freshly prepared Solution $\mathrm{B}$; the $\mathrm{pH}$ of each solution was adjusted to 8.3 with diluted $\mathrm{HCl}$ or $\mathrm{NaOH}$. The tube was immediately stoppered and the solution was stirred to homogeneously distribute the precipitates. The absorbance was measured after $15 \mathrm{~s}$ and $1 \mathrm{~h}$ later. Final calcium concentration ranged between 0.4 to 12.9 $\mathrm{mM}$. Precipitations were carried out at phytate concentrations of 0 to $3.03 \mu \mathrm{M}$.

The solids formed under these experimental conditions were filtered and dissolved in $1 \mathrm{M} \mathrm{HCl}$ and total dissolved calcium and magnesium were determined by atomic emission spectrometry, using an inductively coupled plasma (Perkin-Elmer SL, Optima $5300 \mathrm{DV}$ ) spectrometer. Calcium carbonate crystals formed after $1 \mathrm{~h}$ were filtered, dried in a desiccator and analysed using a scanning electron microscope equipped with an energy dispersive X-ray analyser (EDS).

\section{Calcium carbonate precipitation using a flow system and study of phytate crystallisation inhibitory effects}

Synthetic hard water was recirculated by a multi-channel peristaltic pump for $48 \mathrm{~h}$ at a flow rate of $4 \mathrm{ml} / \mathrm{min}$ through a copper pipe of $200 \mathrm{~mm}$ length, $4 \mathrm{~mm}$ inner diameter and $6 \mathrm{~mm}$ outer diameter (Fig. 1). Synthetic hard water was changed after $24 \mathrm{~h}$ to reduce the effects of supersaturation changes due to crystal deposition on the pipe walls. Crystallisation was performed at a temperature of 30 and $65^{\circ} \mathrm{C}$.

Final calcium concentration ranged from 2.9 to $5.4 \mathrm{mM}$ and the $\mathrm{pH}$ of both solutions was adjusted to 8.0. Precipitation was carried out at phytate concentrations of 0 to $4.55 \mu \mathrm{M}$.

After $48 \mathrm{~h}$ the precipitate on the pipe walls was dissolved

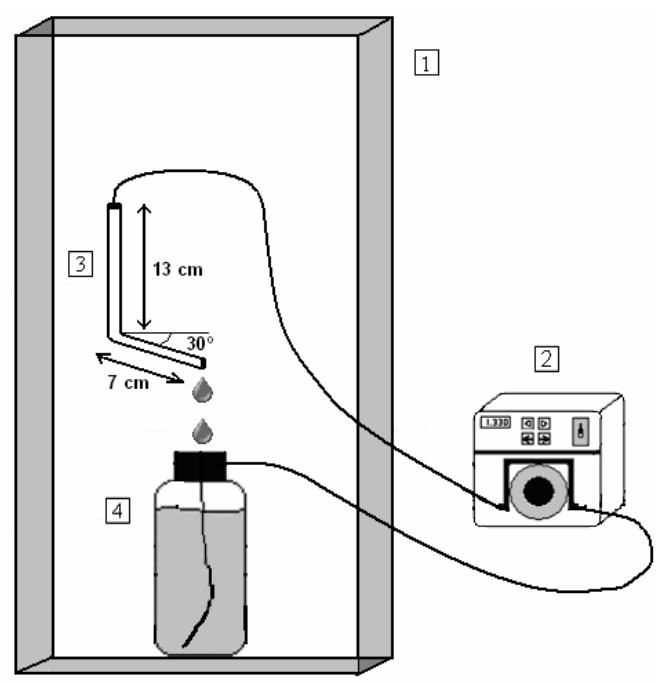

Figure 1

Diagram of the experimental flow system used to study calcium carbonate crystallisation. 1. Temperature-controlled chamber; 2. Peristaltic pump; 3. Copper pipe; 4. Synthetic hard water

in $1 \mathrm{M} \mathrm{HCl}$ and the calcium concentration was determined by atomic emission spectrometry using an inductively coupled plasma (Perkin Elmer Optima 5300 DV) spectrometer.

\section{Full-scale system to study phytate crystallisation inhibitory effects on calcium carbonate precipitation}

A cistern with a capacity of $10000 \ell$ (supplying water to three families) was used to study the inhibitory capacity of phytate in a real system. The cistern was refilled weekly from a natural well filled with hard water. Upon filling the cistern, phytate (as a potassium salt) was added to a final concentration of 0 to $1.52 \mu \mathrm{M}$. After $2 \mathrm{~d}$ of filling, a water sample was collected from a tap of one of the families, and its $\mathrm{pH}$ and calcium and bicarbonate concentrations were measured.

\section{Comparison of the effects of phytate, triphosphate and EDTA on calcium carbonate precipitation reduction using a batch system}

To compare the effects of phytate, triphosphate (as sodium salt) and EDTA (as sodium salt) on calcium carbonate crystallisation, kinetic turbidimetric measurements were performed by means of a photometer (Metrohm 662) equipped with a fibre-optic light guide measuring cell with an attached light path 2 x $10 \mathrm{~mm}$ reflector, using monochromatic light $(550 \mathrm{~nm})$. Crystallisation processes were carried out in a thermostated $\left(25^{\circ} \mathrm{C}\right)$ and magnetically stirred cylindrical glass flask (height $12.5 \mathrm{~cm}$, diameter $9 \mathrm{~cm}$ ). $250 \mathrm{~m} \ell$ of a $6 \mathrm{mM} \mathrm{CaCl}_{2}$ solution were added to the crystallisation flask, the measuring cell was immersed in the solution and the magnetic stirrer was switched on. Then $250 \mathrm{~m} \ell$ of a solution of $11.67 \mathrm{mM} \mathrm{NaHCO}_{3}$ were added. Final calcium and carbonate concentrations were $3 \mathrm{mM}$ and $5.82 \mathrm{mM}$ respectively. The $\mathrm{pH}$ of both solutions was adjusted to 8.5 with diluted $\mathrm{HCl}$ or $\mathrm{NaOH}$. The range of additives concentrations assayed were 0 to $3.03 \mu \mathrm{M}$ for phyate, 0 to $408 \mu \mathrm{M}$ for triphosphate and 0 to $2000 \mu \mathrm{M}$ for EDTA, the chart recorder was immediately switched on in order to print the absorbance-time curve. A diagram of the experimental device used is shown in Fig. 2. 
Figure 2

Diagram of the experimental device used to compare the effects of phytate, triphosphate and EDTA on calcium carbonate crystallisation. 1. Recorder;

2. Altern tension stabiliser;

3. Photometer equipped with a fibre-optic light-guide measuring cell; 4. Thermostatic bath; 5. Magnetic stirrer.

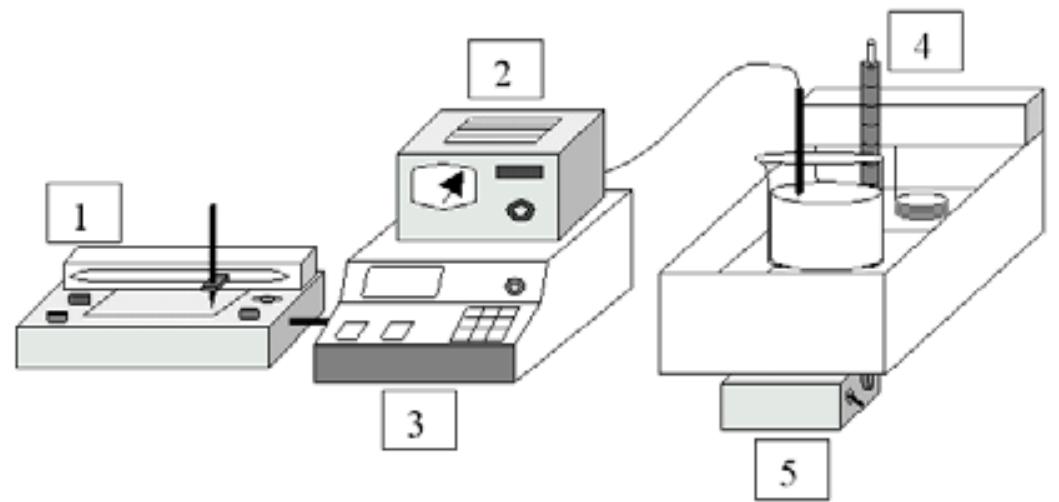

(a)

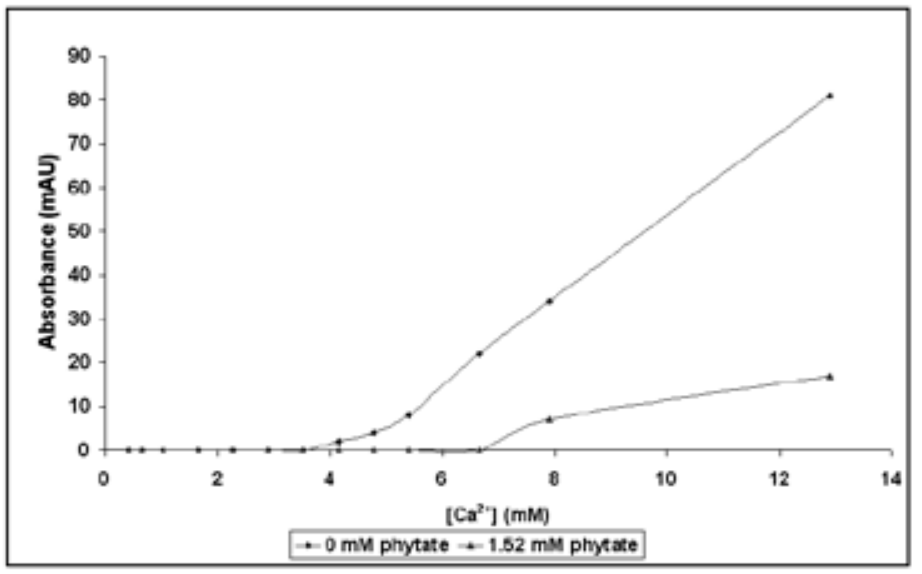

(b)

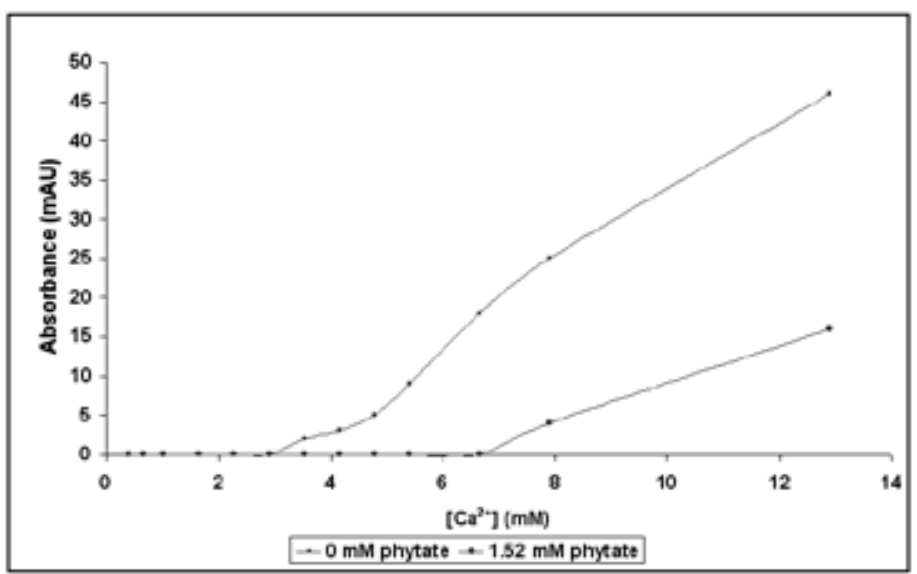

\section{Results and discussion}

Throughout these experiments, controls were utilised, consisting of inhibitor concentration $0 \mu \mathrm{M}$, with each water matrix to ensure that the reduction of calcium carbonate crystallisation was due only to the effects of phytate and not to other compounds.

Using the batch system, it was found that only calcium carbonate was formed, with no precipitation of mixed magnesium salts. Scanning electron microscopy (SEM) of the calcium carbonate crystals formed after $1 \mathrm{~h}$ revealed that the crystallographic structure corresponded to calcite (Fig. 3), with no magnesium present in the precipitated samples. Addition of 1.52 $\mu \mathrm{M}$ phytate to the synthetic hard water completely inhibited calcium carbonate precipitation when calcium concentrations were below $6.65 \mathrm{mM}$ and when the carbonate concentration was 5.83 $\mathrm{mM}$ (Fig. 4). Drinkable hard water contains 2.5 to $3 \mathrm{mM}$ cal- cium and 3.33-8.33 mM carbonate, and has a $\mathrm{pH}$ of 6.5 to 8.5 . Thus, $1.52 \mu \mathrm{M}$ phytate can inhibit crystallisation of calcium carbonate in drinkable hard water. The reduction in crystallisation is probably not due to the formation of Ca-phytate complexes, since phytate is present at a 1000 -fold lower concentration than calcium.

The results obtained using the flow system are shown in Tables 2 and 3 and Fig. 5. This experimental device was designed using conditions as close as possible to actual concentrations of calcium (2.9 to $5.4 \mathrm{mM}$ ) and $\mathrm{pH}(8.0)$. The amount of $\mathrm{CaCO}_{3}$ precipitated was directly related to the calcium concentration in the synthetic water. In the presence of $2.9,3.4$ and $5.4 \mathrm{mM}$ of calcium, $3.03 \mu \mathrm{M}$ phytate reduced the degree of $\mathrm{CaCO}_{3}$ scale formation on the copper pipe after $48 \mathrm{~h}$ by $82.8 \%, 94.5 \%$ and $95.0 \%$, respectively, at $30^{\circ} \mathrm{C}$. The degree of precipitation was higher at $65^{\circ} \mathrm{C}$ than at $30^{\circ} \mathrm{C}$, due to an increase in the kinetics of crystallisation and the decrease of calcium carbonate solubility 


\begin{tabular}{|c|c|c|c|c|c|}
\hline \multicolumn{6}{|c|}{$\begin{array}{l}\text { TABLE } 2 \\
\text { Percent inhibition of calcium carbonate precipitation using the flow system at } 30^{\circ} \mathrm{C} \\
(n=3)\end{array}$} \\
\hline \multicolumn{2}{|c|}{$\left[\mathrm{Ca}^{2+}\right]=2.9 \mathrm{mM}$} & \multicolumn{2}{|c|}{$\left[\mathrm{Ca}^{2+}\right]=3.4 \mathrm{mM}$} & \multicolumn{2}{|c|}{$\left[\mathrm{Ca}^{2+}\right]=5.4 \mathrm{mM}$} \\
\hline [phytate] $(\mu \mathrm{M})$ & $\%$ inhibition & [phytate] $(\mu \mathrm{M})$ & $\%$ inhibition & [phytate] $(\mu \mathrm{M})$ & $\%$ inhibition \\
\hline 0 & - & 0 & - & 0 & - \\
\hline 1.52 & $67.9 \pm 9.2$ & 1.52 & $89.5 \pm 1.9$ & 1.52 & $82.8 \pm 3.9$ \\
\hline 3.03 & $82.8 \pm 0.7$ & 3.03 & $94.50 \pm 0.04$ & 3.03 & $95.0 \pm 2.1$ \\
\hline 4.55 & $82.5 \pm 1.0$ & 4.55 & $92.5 \pm 1.3$ & 4.55 & $93.1 \pm 2.6$ \\
\hline
\end{tabular}

(a)

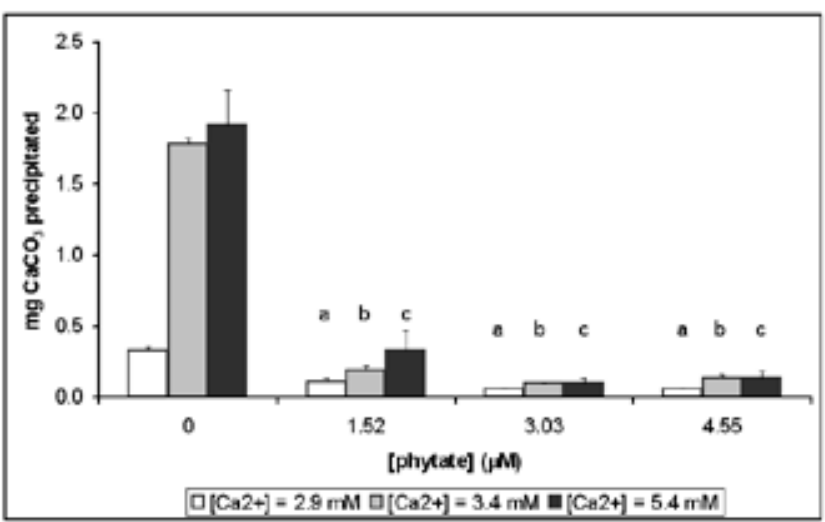

(b)

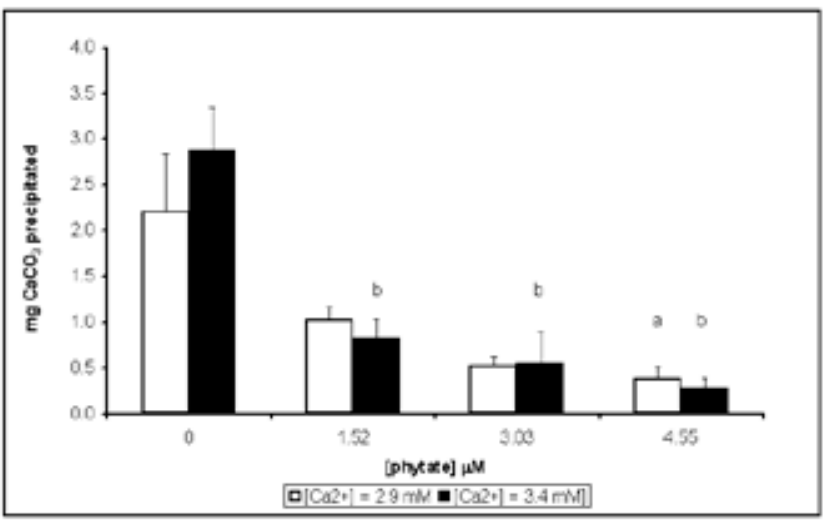

Figure 5

Flow system of calcium carbonate precipitation and the inhibitory effects of phytate. Experimental conditions: $\mathrm{pH}=8.0, t=48 \mathrm{~h}$

a. $T=30^{\circ} \mathrm{C} \quad$ a $p<0.05$ vs $[$ phytate $]=0 \mu \mathrm{M},\left[\mathrm{Ca}^{2+}\right]=2.9 \mathrm{mM}$ ${ }^{b} p<0.05$ vs $[$ phytate $]=0 \mu \mathrm{M},\left[\mathrm{Ca}^{2+}\right]=3.4 \mathrm{mM}$ ${ }^{c} p<0.05$ vs [phytate $]=0 \mu \mathrm{M},\left[\mathrm{Ca}^{2+}\right]=5.4 \mathrm{mM}$ b. $T=65^{\circ} \mathrm{C} \quad$ a $p<0.05$ vs $[$ phytate $]=0 \mu \mathrm{M},\left[\mathrm{Ca}^{2+}\right]=2.9 \mathrm{mM}$ ${ }^{b} p<0.05$ vs $[$ phytate $]=0 \mu \mathrm{M},\left[\mathrm{Ca}^{2+}\right]=3.4 \mathrm{mM}$

at the higher temperature (Table 3). A maximum diminution of $90.8 \%$ was attained at a calcium concentration of $3.4 \mathrm{mM}$ and a phytate concentration of $4.55 \mu \mathrm{M}$, again showing that very low concentrations of phytate can reduce calcium carbonate formation in a flowing system.

The results obtained with a full-scale system, at high calcium and bicarbonate concentrations, are summarised in Table 4. Calcium carbonate precipitation was indirectly evaluated by determining the concentrations of dissolved calcium and carbonate ions. When calcium carbonate is precipitated, the calcium and carbonate concentrations in the cistern should decrease. Thus, if precipitation is inhibited by the addition of a crystallisation inhibitor, the calcium and bicarbonate concentrations should be higher. We found that increasing the phytate concentration in the cistern increased the concentrations of dissolved

\begin{tabular}{|c|c|c|c|}
\hline \multicolumn{4}{|c|}{ TABLE 3 } \\
$\begin{array}{c}\text { Percent inhibition of calcium carbonate } \\
\text { precipitation using the flow system at } \mathbf{6 5}{ }^{\circ} \mathbf{C}(\mathbf{n}=\mathbf{3})\end{array}$ \\
\hline \multicolumn{2}{|c|}{$\left[\mathbf{C a}^{2+}\right]=\mathbf{2 . 9} \mathbf{~ m M}$} & \multicolumn{2}{c|}{$\left[\mathbf{C a}^{2+} \mathbf{~}_{\mathbf{3}} \mathbf{3 . 4} \mathbf{~ m M}\right.$} \\
\hline $\begin{array}{c}\text { [phytate] } \\
(\boldsymbol{\mu} \mathbf{M})\end{array}$ & $\begin{array}{c}\% \\
\text { inhibition }\end{array}$ & $\begin{array}{c}\text { [phytate] } \\
(\boldsymbol{\mu M})\end{array}$ & $\begin{array}{c}\% \\
\text { inhibition }\end{array}$ \\
\hline 0 & - & 0 & - \\
\hline 1.52 & $53.2 \pm 6.4$ & 1.52 & $71.3 \pm 7.2$ \\
\hline 3.03 & $76.2 \pm 4.8$ & 3.03 & $81.0 \pm 12.5$ \\
\hline 4.55 & $82.7 \pm 6.2$ & 4.55 & $90.8 \pm 4.5$ \\
\hline
\end{tabular}

\begin{tabular}{|c|c|c|c|}
\hline \multicolumn{4}{|c|}{$\begin{array}{c}\text { TABLE } 4 \\
\begin{array}{c}\text { Water parameters determined with the } \\
\text { full-scale system }\end{array}\end{array}$} \\
\hline $\begin{array}{c}\text { [Phytate] } \\
(\mu \mathrm{M})\end{array}$ & $\mathrm{pH}$ & $\begin{array}{c}{[\mathrm{Ca} 2+](\mathrm{mM})} \\
\pm \mathrm{SE}\end{array}$ & $\begin{array}{c}{\left[\mathrm{HCO}_{3}^{-}\right](\mathrm{mM})} \\
\pm \mathrm{SE}\end{array}$ \\
\hline 0 & 7.92 & $2.69 \pm 0.02$ & $5.10 \pm 0.03$ \\
\hline 0.15 & 8.00 & $2.70 \pm 0.01$ & $5.10 \pm 0.03$ \\
\hline 0.38 & 7.71 & $2.86 \pm 0.09$ & $5.40 \pm 0.03^{*}$ \\
\hline 0.76 & 7.40 & $2.84 \pm 0.03 *$ & $5.70 \pm 0.03^{*}$ \\
\hline 1.52 & 7.43 & $3.02 \pm 0.01 *$ & $5.90 \pm 0.03 *$ \\
\hline
\end{tabular}

calcium and bicarbonate, showing that phytate can inhibit formation of calcium carbonate solids due to its ability to inhibit crystallisation.

Comparing the effects of phytate, triphosphate and EDTA on calcium carbonate crystallisation (Fig. 6) it can be observed that phytate provoked a maximum delay on calcium carbonate crystallisation at very reduced concentrations, reaching a time of nucleation of $24.3 \mathrm{~h}$ with $3.03 \mu \mathrm{M}$ of phytate. Working with EDTA, a concentration of $2000 \mu \mathrm{M}$ was necessary to obtain the same effect as phytate. This is due to the fact that phytate acts as a crystallisation inhibitor whereas the action of EDTA is as a chelating agent. The maximum inhibitory effects caused by triphosphate were observed with a concentration of $54 \mu \mathrm{M}$. When increasing the concentration to get a major delay of crystallisation it was found that the nucleation time decreased, probably due to the crystallisation of calcium phosphate salts. This comparison demonstrates that phytate clearly delays the crystallisation of calcium carbonate at concentrations in the micromolar range, therefore being superior to triphosphate and EDTA (chelating agent) in this regard.

Crystallisation inhibitory properties of phytate had been previously studied using other calcium salts. It was demonstrated that phytate is a powerful inhibitor of heterogeneous nucleation of calcium oxalate (Grases $(1991 ; 1994)$ ), homogeneous nucleation of calcium phosphates (Grases, 1996a) and crystal growth of calcium oxalate (Grases, 1989) due to its selfadsorption on nuclei in formation or on the faces of a growing crystal. The results with the batch systems presented in 
(a)

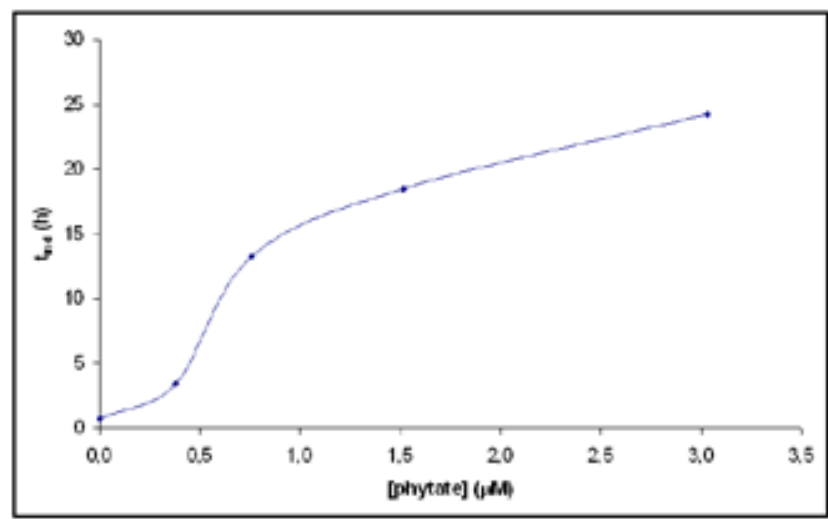

(b)

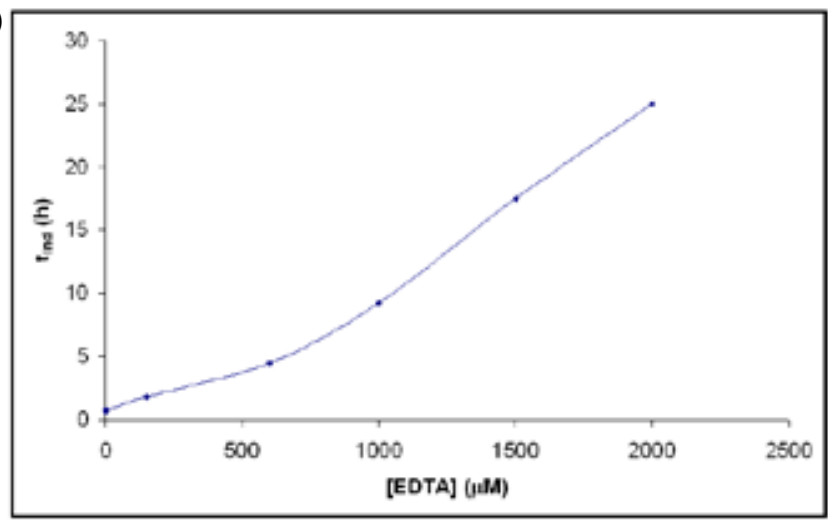

(c)

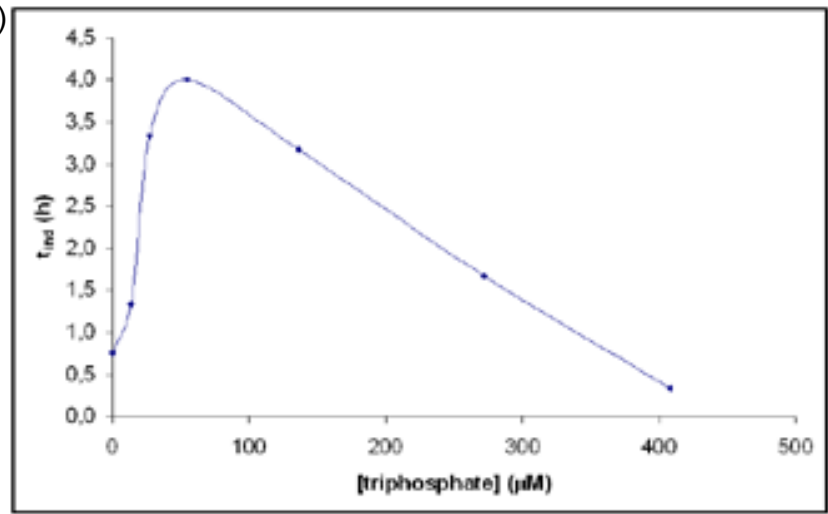

Figure 6

Compared effects of different additives on calcium carbonate crystallisaton

a. Phytate

b. EDTA

c. Triphosphate

this paper, demonstrate that phytate can inhibit homogeneous nucleation of calcium carbonate, whereas the results obtained working with the flow system show that phytate at very reduced concentrations can inhibit heterogeneous nucleation of calcium carbonate.

Phytate is a natural compound that, at these concentrations, is non-toxic. Moreover, it can be beneficial to human health, due to its antioxidant, anti-neoplasic properties (Shamsuddin, 1997; Owen, 1996; Vucenik, 1998) and its prevention of calcium renal lithiasis (Grases $(1999 ; 2000$ a) and cardiovascular calcifications (Grases 2006). Focusing the discussion on water treatment, the effect of phytate on inhibiting calcium carbonate scale formation is directly related to its effect on calcium renal lithiasis and cardiovascular calcifications. In the three cases phytate acts as a crystallisation inhibitor by self-adsorption on the calcium crystal in formation or growth and, although they represent very different research fields they are a consequence of the same chemical effect. Conventional hard water treatment methods, including reverse osmosis, precipitation or ionic exchangers, are based on reducing supersaturation, eliminating the ions responsible for water hardness. Few domestic or industrial systems incorporate crystallisation inhibitors to reduce the degree of scale formation. Other methods, such as the addition of EDTA, may have negative effects on human health and the environment. Although phosphorus-containing compounds have been used as detergent additives to prevent calcium carbonate scale formation, due to the ability of these compounds to chelate calcium and magnesium, they can lead to eutrophication by increasing phosphate concentration in the receiving water bodies. In this paper, we present a methodology for hard water treatment based on the incorporation of phytate, a crystallisation inhibitor that does not change water supersaturation with respect to calcium carbonate. Phytate does not have a negative impact on the environment (i.e. eutrophication) since it inhibits crystallisation rather than acting as a chelating agent. Thus, the phytate concentrations required to significantly reduce the degree of calcium carbonate crystallisation are in the micro-molar range.

\section{Conclusions}

These results show that very low concentrations of phytate may prevent calcium carbonate scale formation due to its ability to inhibit crystallisation. At these concentrations, phytate may be beneficial for human health, mainly in the field of calcium renal lithiasis (Grases, 2000c) and cardiovascular calcifications (Grau, 2005) and will not have deleterious environmental effects.

\section{Acknowledgements}

B.I. expresses his appreciation to the Conselleria d'Innovació $\mathrm{i}$ Energia del Govern de les Illes Balears for a fellowship. Also, J.P. expresses his appreciation to the Spanish Ministry of Education and Science for a Torres Quevedo subvention. This work was supported by the Conselleria d'Innovació i Energia del Govern de les Illes Balears (Grant PROIB-2002GC1-04) and by the project BQU 2003-01659 of the Spanish Ministry of Science and Technology

\section{References}

ARAI H and AOKI M (1968) Effects of oily soils and builders on detergency. Kogyo Kagaku Zasshi 71 (1) 99-104.

COETZEE PP, YACOBY M, HOWELL SS and MUBENGA K (1998) Scale reduction and scale modification effects induced by zinc and other metal species in physical water treatment. Water $S A \mathbf{2 4}$ (1) $77-84$.

GRASES F and MARCH JG (1989) A study of some phosphate derivatives as inhibitors of calcium oxalate crystal growth. J. Crystal Growth 96 (4) 993-995.

GRASES F and COSTA-BAUZÁ A (1991) Potentiometric study of the nucleation of calcium oxalate in the presence of several additives. Clin. Chem. Enzym. Comms 3 319-328.

GRASES F, KROUPA M and COSTA-BAUZÁ A (1994) Studies on calcium oxalate monohydrate crystallization. Influence of inhibitors. Urol. Res. 22 (1) 39-43.

GRASES F, GARCÍA-FERRAGUT L, COSTA-BAUZÁ A and MARCH JG (1996a) Study of the effects of different substances on the early stages of papillary stone formation. Nephron 73 (4) 561-568. 
GRASES F, GARCÍA-FERRAGUT L and COSTA-BAUZÁ A (1996b) Study of the early stages of renal stone formation: Experimental model using urothelium of pig urinary bladder. Urol. Res. 24 (5) 305-311

GRASES F and COSTA-BAUZÁ A (1999) Phytate (IP6) is a powerful agent for preventing calcifications in biological fluids: Usefulness in renal lithiasis treatment. Anticancer Res. 19 (5A) 3717-3722.

GRASES F, PRIETO RM, SIMONET BM and MARCH JG (2000a) Phytate prevents tissue calcifications in female rats. BioFactors $\mathbf{1 1}$ (3) $171-177$

GRASES F, RAMIS M and COSTA-BAUZÁ A (2000b) Effects of phytate and pyrophosphate on brushite and hydroxyapatite crystallization. Comparison with the action of other polyphosphates. Urol. Res. 28 (2) 136-140.

GRASES F, MARCH JG, PRIETO RM, SIMONET BM, COSTABAUZÁ A, GARCÍA-RAJA A and CONTE A (2000c). Urinary phytate in calcium oxalate stone formers and healthy people. Scand. J. Urol. Nephrol. 34 (3) 162-164.

GRASES F, SIMONET BM, PRIETO RM and MARCH JG (2001a) Variation of $\mathrm{InsP}_{4}, \mathrm{InsP}_{5}$ and $\mathrm{Ins}_{6}$ levels in tissues and biological fluids depending on dietary intake. J. Nutr. Biochem. 12 (10) 595 601.

GRASES F, SIMONET BM, VUCENIK I, PRIETO RM, COSTABAUZA A, MARCH JG and SHAMSUDDIN AM (2001b) Absorption and excretion of orally administered inositol hexaphosphate (IP 6 or phytate) in humans. Biofactors 15 (1) 53-61.

GRASES F, SIMONET BM, PERELLÓ J, COSTA-BAUZÁ A and PRIETO RM (2004) Effect of phytate on element bioavailability in the second generation of rats. J. Trace Elem. Med. 17 (4) 229-234

GRASES F, SANCHIS P, PERELLÓ J, ISERN B, PRIETO RM, FERN ÁNDEZ-PALOMEQUE C, FIOL M, BONNIN O and TORRES JJ (2006) Phytate (myo-inositol hexakisphosphate) inhibits cardiovascular calcifications in rats. Front Biosci. 11 136-142.

GRASES F, SANCHIS P, PERELLÓ J, ISERN B, PRIETO RM, FERNÁNDEZ-PALOMEQUE C and TORRES JJ (2007) Effect of crystallization inhibitors on vascular calcifications induced by vitamin $\mathrm{D}$. Circ. J. 71 (7) 1152-1156 (2007).

GRAU A, FERNÁNDEZ-PALOMEQUE F, GRASES F, SANCHIS P, PERELLÓ J, ISERN B, COSTA-BAUZÁ A, VIDAL L, MORANTA E, ACEÑA M, CALDÉS O, BONNIN O, GARCÍA-RAJA A and BETHENCOURT A (2005) Relación entre el fitato y calcificaciones valvulares cardíacas. Estudio de campo para diseño de un ensayo clínico en la estenosis aórtica. IV Congreso de la Sociedad Balear de Cardiología. Palma de Mallorca, Spain.

GUO J and SEVERTSON SJ (2004) Inhibition of calcium carbonate nucleation with aminophosphonates at high temperature, $\mathrm{pH}$ and ionic strength. Ind. Eng. Chem. Res. 43 (17) 5411-5417.

GWON HS and JEON GS (2002) Water Softener Rotationally Circulating Ion Resin. Patent: Repub. Korean Kongkae Taeho Kongbo.

HASSON D, SEMIAT R, ILEVICHY M, DAMIANO D and SHER A (2004) Inhibition of $\mathrm{CaCO}_{3}$ scale deposition by trace concentrations of some common ions. Proc. AWWA Water Quality Conf., 14-18 November, Texas, USA.

HIRAYAMA T (1990) Apparatus and Method for Purification of Drinking Water by Reverse Osmosis. Patent: Jpn. Kokai Tokkyo Koho.

HOU W and FENG Q (2005) A simple method to control the polymorphs of calcium carbonate in $\mathrm{CO}_{2}$-diffusion precipitation. $J$. Cryst. Growth 282 (1-2) 214-219.

ICHIKAWA H, OHISHI S, TAKAHASHI O, KOBAYASHI H, YUZAWA K, HOSOKAWA N and HASHIMOTO T (1987) Acute oral toxicities of phytic acid and sodium phytate in rats. Kenkyu Nenpo-Tokyo-toritsu Eisei Kenkyusho 38 371-376.
KABAY N, DEMIRCIOGLU M, ERSOZ E and KURUCAOVALI I (2002) Removal of calcium and magnesium hardness by electrodialysis. Desalination 149 (1-3) 343-349.

KANG SH, HIRASAWA I, KIM, WS and CHOI CK (2005) Morphological control of calcium carbonate crystallized in reverse micelle system with anionic surfactants SDS and AOT. J. Colloid Interface Sci. 288 (2) 496-502.

KIM II W, ROBERTSON RE and ZAND R (2005) Effects of some nonionic polymeric additives on the crystallization of calcium carbonate. Cryst. Growth Des. 5 (2) 513-522.

KLEPETSANIS PG, KOUTSOUKOS PG, CHITANU GC and CARPOV A (1998) The inhibition of calcium carbonate formation by copolymers containing maleic acid. Water Soluble Polymers: Solution Properties and Applications. Proc. Symp. on Water Soluble Polymers: Solution Properties and Applications, 7-11 November. Las Vegas, USA.

KLEPETSANIS PG, KOUTSOUKOS PG and AMJAD Z (1999) Calcium carbonate and calcium phosphonate scale formation at elevated temperatures: Inhibition. Book of Abstracts, 218 th ACS National Meeting, 7-11 November. New Orleans, USA.

KLEPETSANIS PG, KOUTSOUKOS PG and AMJAD Z (2000) Calcium carbonate and calcium phosphate scale formation and inhibition at elevated temperature. Proc. ACS Symp. entitled Advances in Crystal Growth Inhibition Technologies, 7-11 November. New Orleans, LA, USA.

MACADAM J and PARSONS SA (2004) Calcium carbonate scale control, effect of material and inhibitors. Water Sci. Technol. 49 (2) 153-159.

MALIK MS, IQBAL MJ, KHAN GR and ALUNAD R (2001) Development of indigenous technology for the production of synthetic zeolite of high cation exchange capacity as water-softener. Proc. Pak. Acad. Sci. 38 (2) 151-156.

NANCOLLAS GH (1975) The formation and dissolution of calcium carbonate minerals. Thalassia Jugosl. 11 (1-2) 37-45

OWEN RW, WEISGERBER UM, SPIEGELHALDER B and BARTSCH H (1996) Fecal phytic acid and its relation to other putative markers of risk of colorectal cancer. Gut 38 (4) 591-597.

REDDY MM and NANCOLLAS GH (1972) Effect of phosphates and phosphonates on nucleation and crystal growth of calcium carbonate. Preprints of Papers Presented at National Meeting, Division Water, Air and Waste Chemistry. J. Am. Chem. Soc. 12 (2) 212-216.

REDDY MM and NANCOLLAS GH (1973) Calcite crystal growth inhibition by phosphonates. Desalination 12 (1) 61-73.

REDDY MM and WANG KK (1980) Crystallization of calcium carbonate in the presence of metal ions. I. Inhibition by magnesium ion at pH 8.8 and $25^{\circ}$ C. J. Cryst. Growth 50 (2) 470-80.

SEMENOV SA (2004) Experimental researches of application of natural zeolites in technologies for water-preparation of municipal boiler-houses. Izvestiya Vysshikh Uchebnykh Zavedenii, Problemy Energetiki (3-4) 27-33.

SHAMSUDDIN AM, VUCENIK I and COLE KE (1997) IP6: a novel anti-cancer agent. Life Sci. 61 (4) 343-354.

SIKES CS and WHEELER AP (1988) Regulators of biomineralization. Chemtech. 18 (10) 620-626.

TOTI US, KARIDURAGANAVAR MY, BALUNDGI RH and AMINABHAVI TM (2000) Electrodialysis membrane technology for purification of brackish ground water. Polym. News 25 (3) 80-86.

VUCENIK I, TANTIVEJKUL K, ZHANG ZS, COLE KE, SALED I and SHAMSUDDIN AM (1998) IP6 in treatment of liver cancer I. IP6 inhibits growth and reverses transformed phenotype in HepG2 human liver cancer cell line. Anticancer Res. 18 (6A) 4083-4090

WESTIN KJ and RASMUSON AC (2005) Crystal growth of aragonite and calcite in presence of citric acid, DTPA, EDTA and pyromellitic acid. J. Colloid Interface Sci. 282 (2) 359-369. 